\title{
THE ATTITUDES OF NCE STUDENTS TOWARDS USE OF INTERNET AT USCOEGA
}

\author{
Abdulrahman Yusuf \\ Faculty of Science, Department of Computer Science \\ Yobe State University, P.M.B. 1144, Damaturu, Nigeria. \\ audura33@yahoo.com.
}

\begin{abstract}
This research work examines the attitudes of Nigerian Certificate in Education (NCE) students towards use of InternetatUmar Sulaiman College of Education Gashua (USCOEGA) in the year 20010/11 academic session. In this connection therefore, the study aims at studying the effect of certain variables such as gender, computer/Internet experiences and Internet perception on learning process at different schools and levels in the college. A survey was carried out with a sample of 240 students from various schools and levels in the USCOEGA. A questionnaire was designed and distributed to the students' sample. Surprisingly, the result revealed a limited awareness about the important and the usage of Internet among NCE students and the NCE students learning has no relationship with the usage of Internet. However it was shown that gender has no significant effect towards Internet usage. Furthermore, the study also vindicated that the token amount being paid for the Internet services stops most students from using Internet; in addition to that, contradicted findings were also discovered as a result of falsification of information by some students: conclusively, some list of recommendations were given base on the findings.
\end{abstract}

Keywords: Internet; e-learning and ICT.

\section{Council for Innovative Research}

Peer Review Research Publishing System

\section{Journal: International Journal of Management \& Information Technology}

Vol. 10 No. 3

editorsijmit@gmail.com

www.ijmit.com/ojs 


\subsection{INTRODUCTION}

The use of technology in a class room has increasingly been the subject of many studies in the recent years. The Internet is considered to be the most prominent invention in modern technology as well as the modern revolution of information and communication technology. Thelnternet has existed for about40 years and therefore its surge of mainstream popularity motivated researchers, teachers and students to appreciate its educational values. The wide spread of Internet can be used in many educational and scientific fields. This makes the Nigerian educational supporting bodies build Internetaccess point in numerous schools of higher learning. Furthermore, literature on educational technology shows that the use of Internet in teaching learning process has potentially motivated both students and teachers.

According to [21] and Teresa[22] the introduction of Internetservices at various institutions of higher learning will make researchto revolutionary change in the way of improving students' intellectual skills compare to the traditional learning. It is also indicated that the successful use of the Internet in education is wholly based on the availability and enthusiasm of teaching and learning.

The use of Internet in education has many advantages to attain such as rapid knowledge acquirement, flexibility in term of time and place, the style of teaching has changed from lecturing to guide and monitor, the study materials can be gotten at any time and any location as well as various views of scientists and scholars from different disciplines. Research has proved that the successful use of Internet in tertiary institutions has opened the new horizon to develop the learning process and provide students with new and more flexible ways of learning among others.

\subsection{Background of the Study}

The Internet was initially called ARPANETand the mission was for two or more computers to communicate as well as share information for research and development in scientific and military aspects. In 1962 Licklider J. proposed a global network of computers. As the research had continuedthe mission actualized.ARPANET was conveyed on-line in 1969 by the Advance Research Project Agency (ARPA).ARPA had experienced a lot of changes in name. Hence forth, many research centers of Americanuniversities were connected. With time,Internet connectivityhas been increasingly accommodated worldwide as we experience today [18].

Internets facilities are used for different purposes among others are commercial, social, above all educational and many others. USCOEGA is the only state college of education in the state which was established in 1986 since then Borno state Government. It was established to achieve the following objectives:

- to provide the course of study, training and research in arts, languages and science leading to the award of NCE;

- to provide holders of NCE who will teach in the primary and secondary school in the state;

- $\quad$ to promote thought, teaching, research and other means to the need of the schools and community; and

- to provide courses in the institution both in academic and professional field of studies in the college and others.

Following the proliferations of information and communication technology (ICT),recently, traditional mode of study is integrating with the modern methods (i.e e-learning); USCOEGA is not in exception as such two Internet services have been brought by the Nigerian Educational Supporting Bodies: Educational Trust Fund (ETF) in 2005 and Universal Service Provision Fund (USPF) under the auspices of National Communication Commission in 2008. The Internet services are to facilitate teaching and learning for both staff and student in the college.

Gradually, Internet has become part of every sphere of life. It was Internet that makes on-line education and distance learning possible. Professional working in physically distanced location couldcollaborate efforts. It also provides some of the most effective means of communication. E-Mails and instance messages have made on-line discussion forums to be popular platforms of expression. Therefore, People from different parts of the world can exchange views, share information and work together vialnternet. We do give many thanks to the development being brought bylnternet [18].

World is now become a global village due tolnternetconnectivity. As such,many of the pretty good and bad effects are available. For instance, there are available illegal "schools programs" that are fee based where people believe to have degree within short timebut sometimes end up with nothing, the worse!However, the college students, USCOEGA students inclusive can get many array of materials that can becaptured and retrieved by commonly used web search engines such as Google, are based on keywords to display websites links and information. These are most a time stressful, distressful and possibly misdirect the users, as such, for better Internet use and assessment, proper skills are needed.

\subsection{Research Questions}

In this era of technology, teaching and learning process is one of the key issues for using Internet, as such, the following research questions were formulated to guide this research work:

- What are the attitudes of NCE students towards Internet in thisvery academic session?

- What are the students' perception and impression about Internet?

- $\quad$ Are the students using Internet services?

- If Yes, for what purposes? 
- If No, Why?

\subsection{Statement of the Problem}

Today, most of the schools of higher learning have introduced multiplicity of services in order to go with the new movements and advance in students' knowledge. There is no doubt, the Internet services have become available to all teaching staff and students who utilize this service are notably increasing in various school of higher learning. USCOEGA has Internet laboratory, nevertheless, there may be someissues among the students who have different degree of perception and motivation inInternet usage. These lead the study to find outabout perception, impression and technical skills in the use of Internetamong students in the course of their studies.

The students' attitudes towards use of Internethave been observed as the researcher have noticed wheneverpays a visit the USCOEGAInternet café. This is among what motivate this researcher.

\subsection{Objectives of the Study}

Following the availability of the Internet facility in the college for the purpose of integrating modern means of study with the traditional one, the main aims and objectives of this research work is to investigate the attitudes of students towards using Internet in this very year of academic session. In other word is trying to find out:

- $\quad$ whether or not the students uselnternet for their learning process;

- the impression and perception of NCE students about Internet;

- $\quad$ what motivate studentsto uselnternet in their learning activities and

- $\quad$ finally to come up with possible solution to address the identified problem(s) of students attitudes of using Internet in 2010/2011 academic session.

\subsection{Significant of the Study}

Many factors independently or jointly contribute to the negativeinterest in students' participation towards use of Internet for better academic achievement or experiences. Hence, creating understanding or awareness about the importance and benefits of Internet resources in the learning process could be the most necessary ingredient that will encourage students to be fully patronizing Internet for better academic achievement. It is therefore very necessary and crucial to understand, investigate and bring out possible solution about those factors under investigation.

When the research is completed, the management of various colleges,State Governments and thepeople of the immediate community whose children come to study in the college (especially USCOEGA) would know the status of students in term of Internet use which could make them to take necessary steps for flourishing the situation. In addition, staff, parent and students could understand thestudents' stands in Internetusage which may lead tobetter improvement.

\subsection{Scope and Limitation}

This research is designed to investigate the attitudes of students towards use oflnternet in 2010/2011academic session in USCOEGA but pre-NCE excluded. The study is limited to only this college as well as its NCE I, II and IIIstudents, due to the costs and time constraints.

\subsection{Operational Definition of Terms}

Attitude: - this is the way that someone thinks and feels about something (Internet in this case).

Computer: - is an electronic device which accepts data as input, processes (organizes, does calculations, controls other information and finds information) under the control of stored programs as well as gives out output as information in addition to storing.

Internet: - is the global network of computer networks for data/information exchange between computers fromeducational institutions, government agencies, business organizations and many other networks which are accessible via modem link.

ICT: - stands for Information and Communication Technology -is the use of computers, the Internets, video, and other technological equipment for study in the school.

E-Learning: - this is ambiguous to define; as such it has no worldwideacceptable definition. The definition depends on the context. Here are some: it is learning through computer. In another aspect, e-learning is a learning that is facilitated by the use of electronic tools such as computer, projector, etc. In another definition, e-learning is typically involved some form of interactivity which may include on-line interaction between the learners and their teachers.

NCE: - this is an acronym of Nigerian Certificate in Education - and is a three yearspost-secondary school program aims in producing trained primary or secondary school teachers by the Nigerian colleges of education.

Student: - is a person who studies at secondary school, College, University, etc.

Web:- many people see web and Internetto mean the same but technically are different things. Web is anlnternet subset; in this connection therefore, World Wide Web is the large amount of inter-connected digital information having domain name to locate the data stored on a remote computer that connected to the Internet. 


\subsection{RELATED WORK}

This section discusses the related literature in the use of Internet in teaching process.

\subsection{Internet in Teaching Learning Process}

The use of Internet in education can achieve many advantages like; rapid education, flexibility in time and place, high speed in creating new programmes compared to the system of videos and CD-ROM, changing the style of teaching from lecturing to guidance and monitoring, getting the study materials from any time and any location, and getting the views of scientists and scholars in various fields [14] and [3]. [24]evaluated the level of Internet utilization for academic research at Obafemi Awolowo University, Ile-Ife, Nigeria, and the study revealed that the use of Internet for academic research can significantly improve through the provision of more access point at department and faculty levels. It is observed that, the students now having the behavior of Internet research, some do depend solely on Internet resources for writing research papers, while many of themuse both traditional library materials and online resources. So also, it can be infer that, convenience and accessibility could be the major factors influencing uselnternet in academic.

In fact, the introduction of Internet services to classes is considered significant step towards enhancing the use of the service in the field of learning [3]. Increasingly, students make use of technology to acquire skills and knowledge [19]. According to Rodney [22] and [21], the introduction of Internet services at tertiary institution level will completelychange the way of learning by improving students intellectual skills compared to traditional learning. [8]concluded that the use of Internet can significantly improve the educational measures and it will bring up new ways of teaching at wider scope. Also [13] indicated that, the successful use of the Internet in education is totally based on the accessibility and the enthusiasm of teachers and learners with appropriate training.

[20]in his findings on Internet access and use among students in three Nigerian Universities reveals that Internet is extensively used by undergraduate students, but they mostly relay on private/commercial Internet cyber cafés as a result of access to the Internet in the University libraries, departments/faculties and University computers/ICT centers is obviously poor, this may be due to the lack of Internet infrastructures and connectivity or non-sustainable services in these Universities.

\subsection{Internet Use and Specialization}

[5]conducted a research in recognizing the reality of Internetusage by the faculty members at Jordanian Universities. The study revealed that the proportion of those who use Internet was high and Internet usage was affected by specialization. [7] and [16] studied the importance of Internet use in the field of learning from the University teachers' point of view. The result showed there are significant statistical differences among users and was attributed to differences in specialties (in favour of science and technology) as the real situation of Internetusage among the teachers and students in Jordan University of science and technology. The study by [4] contradicted the other findings which showed that the use of Internet has no relationship with variables of specialty. But the study of [5] revealed significant relationship between specialties and Internet users. These studies also revealed the differences in the degree of computer experience.

\subsection{The Need for Skills Acquisition forlnternet Usage}

In order to use the growing range of electronic resources, students need to acquire and practice the skills necessary to exploit them. For students using a variety of on-line database, it is as they were parking many attendants, where every vehicle is not only a different shape and model but has a different configuration that requires knowledge to use. It seems that the skills require tomaximizeand potentiallyuse electronic resources are technically much more than those required for searching printed sources. These skills include knowledge of structure of the data base and the instructions which must be input in to the search space by the searcher, as well as understanding the ways in which the instructions are linked with one another. It is recommended that it is very important and also necessary to providelnternet training course for students [4]. However, Brophy (1993) in [2] states that users (especially students) do not often appreciate the skills required to search these sources, thinking they are relatively easy to use. The ability to find and retrieve information effectively is a transferable skill useful for future life as well as empowering the positive and effective use of the electronic resources while study in the institution.

\subsection{Information source Evaluation}

Another emphasis has being on students' ability to evaluate the quality of the sources they encounter whiledoing research by using web materials; this may not be far from the skill acquisition for Internet use. Studies have shown that academicians use materials from education and government top-level domain (website) to establish the trust worthiness of the web source. The suggestionby students on web sources needs more training or how to conduct Internet research in general, with emphasis on critical evaluation of all electronic sources and proper citation of the use sources. One can find students approachlnternet for their study issues such as assignments, projects and other research instead to search from library pages they mostlyuse search engines such as yahoo, Google, WebCrawler and Intoseek. These popular resources are used although academicians express doubt about the accuracy and authority of somelnternet sources [17].

\subsection{Internet as a Way of Communication}

Other researchers have begun to explore what students are doing on webs are beyond academics. [9]reports that majority of students use the web to communicate with friends and family via e-mailfor social purposes instead of educational. In a survey of 406 graduates and undergraduates it was shown that the most used Internet service was e-mail: $100 \%$ of the 
chosen sample used e-mail service [15]. According to [18]Internet provides some of the most effective means of communication. E-mail and instant massages have made on-line communication possible. Social networking and on-line discussion forums are proved to be popular platform of expression.

It may be true that in some institutions where Internet access is relatively reliable and seamless, non-academic purposes is one of the key Internet usage categories. A study by [12]shows that $72 \%$ of students check their e-mail at least once in a day and the e-mail is the most popular on-line communication method used by students. However, today social networks such as Facebook, twitter, Whatapps could be popular on-line communication method used by students as they are order of the day in people hands. In [6] survey of students' Internet activities indicated that students spent an average of 100 minutes per day on-line 35 minutes of which were spent on e-mailing.

\subsection{Effects of E-Learning}

The use of web for research hashighlighted the increasing attraction of digital information age. An example of this is increasing in acceptance and embracing of the digital can be found in the case of adoption of the e-materials such as ebooks. It was observed that where e-materialarebeing used, students get bore about having to scroll to find section, about how long it took to scroll, and about the problem of reading from laptop. Students have also reported that the smaller screen of an e-book readers, designed for just this application, makes the books more difficult to read, as the tiny screens made the text seem more fragmented.

Despite e-learning as the modern way of teaching and learning a number of harmful effects to learners engulfed it. Among the harmful effects to e-learners are electromagnetic radiation, straightening of eyes, and distraction of organs [26]. In addition, [25] observed the time consumed for creation and maintenance of e-learning materials as a great challenges. [25] added that the success of e-learning is solelydepended on possession of adequate technical skills for effective use of e-learning tools.

It is also unfortunate to hear that,Internet provides avenue for the evil doers such as theft, scams and other worse activities. Internet appears to be a playground for both good and evil acts.Sexual predators and others with immoral intention have make it where to jeopardize young child. There could be too many illegitimate "schools" and money-based programs where people actually believe that they can get schoolcertificate within a few months, or the worse, pay money and end up with nothing. However, it is true to say that, today, knowledge is obtained and shared morequicklyby Internet.

\subsection{METHODOLOGY}

This part of the project discusses the area, population sampling method, method of data collection, as well as data analysis.

\subsection{Area of the Study}

This research is carried out within the only state college of education situated at Gashu'a, Bade Local Government area, Yobe State.

\subsection{Population and Sample of the Study}

The target population for this study encompasses four schools (4) schools in the college which include school of sciences, school of vocational education, school of arts and social sciences and school of languages. The population is made up of all NCE I, II and III students. A sample of two hundred and forty (240) students is chosen to represent the whole population.

\subsection{Sampling Techniques}

As sampling being the method employ to choose a sample (certain part of population) which could be true representative of the population under study. As such simple random sampling technique (purposive) is used for sample selection in this research work. In this regard, therefore, sixty (60) students were randomlyselected as they come to my way from each school in which twenty (20) students were from every level of NCE I, II and III respectively.

\subsection{Method and Procedures for Data Collection}

The method used for data collection is questionnaire method. Each of the students in the used sample was given the prepared questionnaire by the researcher; but only two hundred and twenty six (226) have been brought back, out of the two hundred and forty (240) delivered that is fourteen (14) were not returned because student were busy preparing for exams, as such they collected the questionnaires and promised to take them back but they couldn't. At least two students from every department in the school and at particular level have answered the questionnaires given to them.

\subsection{Method of Data Analysis}

As do happen in many other studies, this study will use both descriptive and inferential statistics to analyze the collected data for this study. These include bar-chart and chi-square $\left(x^{2}\right)$. Where

$$
\times^{2}=\sum_{i=1}^{i=n} \sum_{j=1}^{j=m} \frac{\left(O_{i j}-E_{i j}\right)^{2}}{E_{i j}}
$$


$O_{i j}=$ observed frequency and $E_{i j}=$ expected frequency

\subsection{DATA PRESENTATION, ANALYSIS AND DISCUSSION}

This section presents an analysis of the data obtained as well as discussion of the result.

\subsection{Data Presentation}

The study collected data from different schools and levels on three variables that is gender, experience and Internet perception as presentedin table 1 below.

Table 1:Responses of students of the questionnaire shown in Appendix I

\begin{tabular}{|l|l|l|l|l|l|l|l|l|l|}
\hline \multirow{2}{*}{ Variables } & \multicolumn{2}{l}{ GENDER } & \multicolumn{2}{l|}{ EXPERIENCE } & \multicolumn{3}{l|}{ INTERNET PERCEPTION } \\
\cline { 2 - 11 } \\
\cline { 2 - 11 }$y$ & Male & Female & Yes & No & SA & A & I & D & SD \\
\hline NCE III & 49 & 31 & 212 & 92 & 265 & 257 & 53 & 105 & 57 \\
\hline NCE II & 48 & 32 & 160 & 172 & 211 & 243 & 142 & 74 & 93 \\
\hline NCE I & 50 & 30 & 160 & 92 & 218 & 267 & 94 & 84 & 87 \\
\hline
\end{tabular}

\subsection{Analysis and Discussion}

To meet the objectives and answer the questions raised in the study, Chi-square, percentage and chart were used.

\subsubsection{Hypothesis Test}

$\mathbf{H}_{1}$ : The students have limited awareness about the importance and experience of Internet in USCOEGA at $\alpha=5 \%$ level.

Table2:Thestudents' experiences about computer and Internet experience

\begin{tabular}{|c|c|c|c|}
\hline & Yes & No & Row Total \\
\hline NCE III & 212 & 92 & 303 \\
\hline NCE II & 160 & 172 & 304 \\
\hline NCE I & 160 & 92 & 894 \\
\hline Column Total & 532 & 362 & 304 \\
\hline
\end{tabular}

The computation of Chi-square of Table 2is performed for statistical decision.

\subsubsection{Statistical Decision of $\mathbf{H}_{1}$}

Since the $x^{2}{ }_{c}>x_{t}^{2}(23.51>5.99)$, the hypothesis is the students in the USCOEGA have limited awareness about the important of Internet usage.

$\boldsymbol{H}_{2}$ : There is no relationship between Internet usage and learning process among NCE students in USCOEGA at $5 \%$ level of significant (i.ed 0.05 )

Table 4: the students' responses about Internet usage

\begin{tabular}{|c|c|c|c|c|}
\hline & POSITVE & NEGETIVE & NEUTRAL & ROW TOTAL \\
\hline NCE III & 243 & 86 & 94 & 423 \\
\hline NCE II & 227 & 84 & 142 & 395 \\
\hline NCE I & 261 & 81 & 53 & 1271 \\
\hline COLUMN TOTAL & 731 & 251 & 289 & \\
\hline
\end{tabular}

The computation of Chi-square of Table 3isperformedfor statistical decision.

\subsubsection{Statistical Decision of $\mathrm{H}_{2}$}

Since the $x_{c}^{2}>x_{t}^{2}(39.78>9.488)$, the hypothesis is accepted; that is there is no relationship between the Internet usage and learning process among NCE students in USCOEGA 


\subsection{Further Discussion of Findings}

There is an important question about whether the NCE students have been taught the importance of Internet and how to use it. $66.33 \%$ of the students answered that they have ever being taught the importance of Internet but $55.22 \%$ they were not taught how to use it.

Have they ever operated computer for whatever purpose? The responses to this question are shown in Table 4 below where the distribution of the computer operation among the students indicated that $50 \%$ of the studentshave not ever operate computer. But there is equal distribution in both male and females in computer operation that is gender has no effect in this aspect.

Table 4: Distribution of Computer Operations

\begin{tabular}{|l|l|l|l|l|l|l|l|l|}
\hline SCHOOLS & \multicolumn{2}{|c|}{ Sciences } & Art \& Social Sciences & \multicolumn{2}{c|}{ Vocational } & \multicolumn{3}{c|}{ Languages } \\
\hline RSPONSES & Yes & No & Yes & No & Yes & No & Yes & No \\
\hline NCE III & 10 & 08 & 09 & 08 & 13 & 07 & 08 & 12 \\
\hline NCE II & 12 & 07 & 10 & 08 & 06 & 14 & 04 & 14 \\
\hline NCE I & 09 & 11 & 13 & 07 & 11 & 08 & 08 & 09 \\
\hline
\end{tabular}
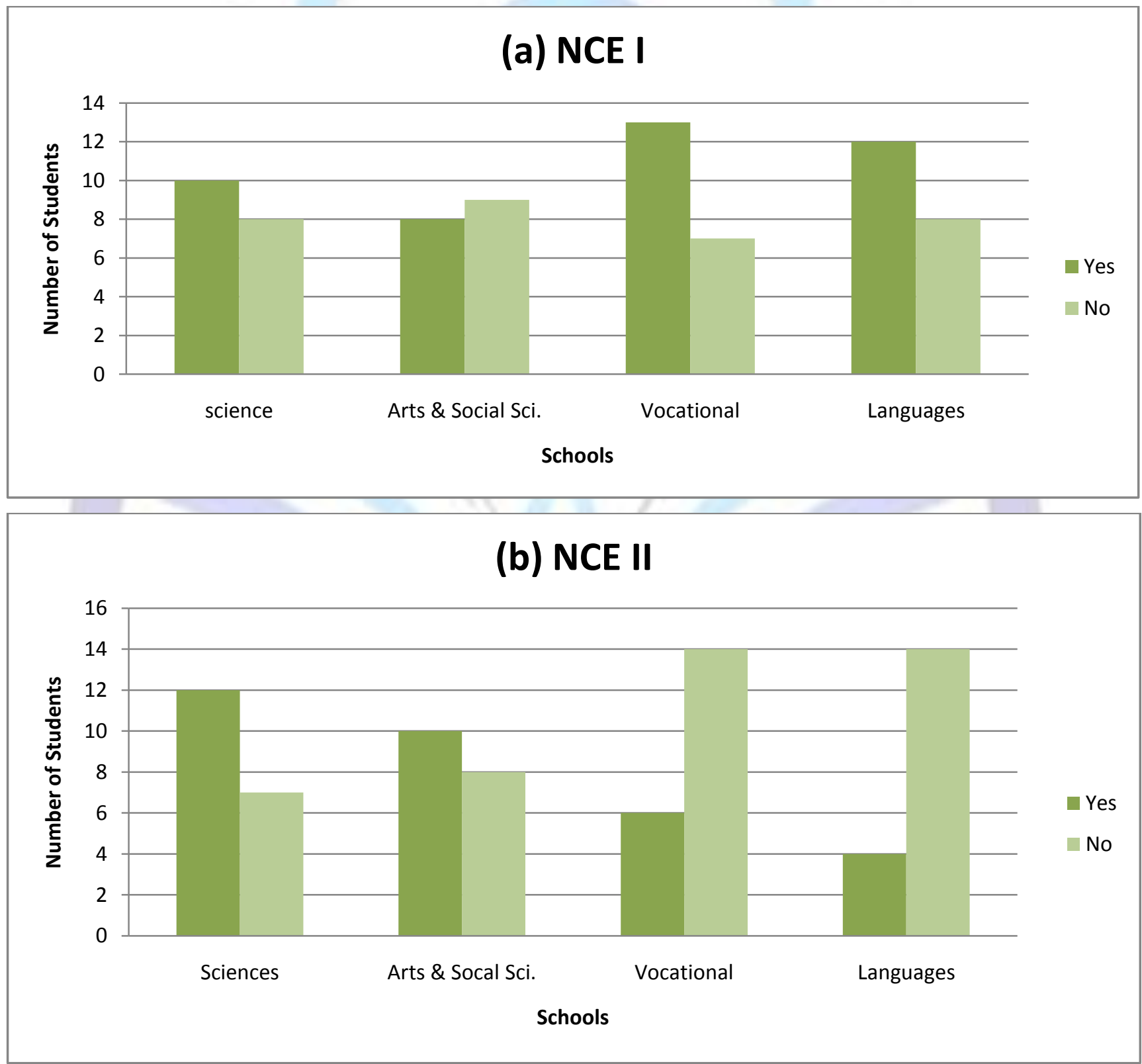


\section{(c) NCE III}

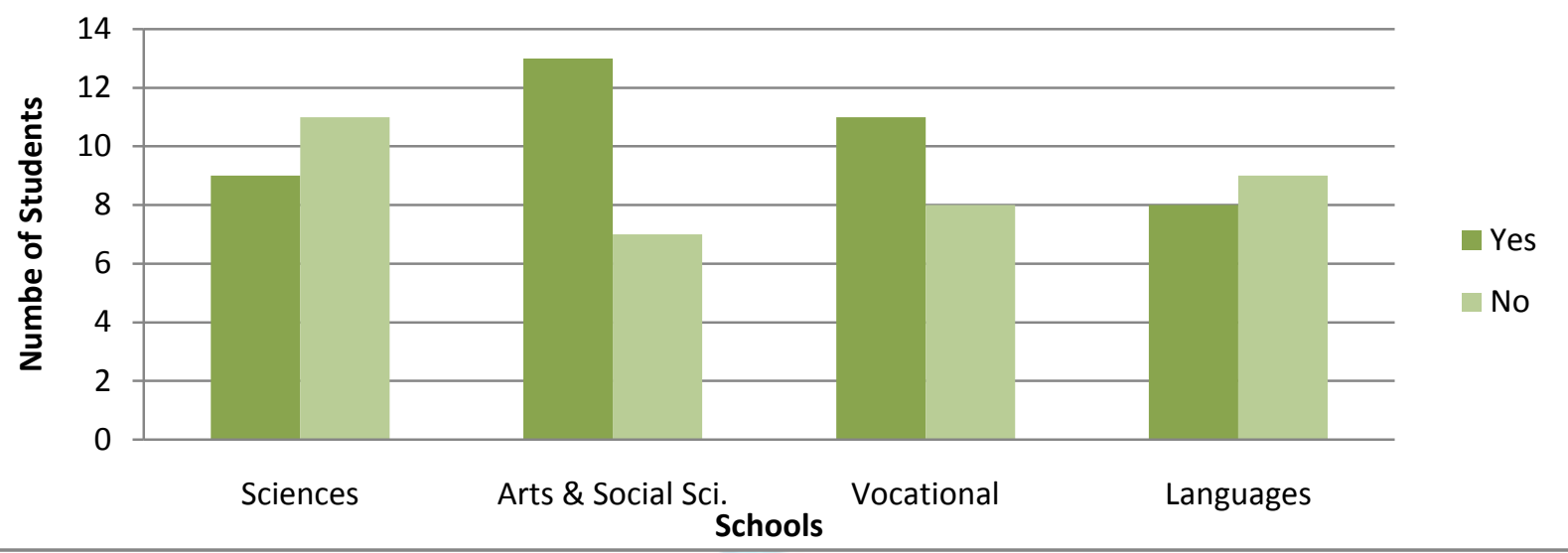

Chart 1: Bar-charts show the proportions of students know how to operate computer at different NCE levels.

From the three charts above, it is clearly revealed that majority of the students from the school of languages have very little experience about using computer for whatever purposes let alone accessing Internet for their studies. So also, many students of NCE II and NCE III from schools of vocational and science respectively have some little knowledge on how to operate computer.

In response to anotherquestion, many of the studentssaid whatstopped them from accessing the Internetwas the token amount been paid for the Internetservices;Table 5below records the responses of students in which $68.81 \%$ agreed that it is the token amount while $31.19 \%$ disagreed.

Table 5: Students Responses about the question above

\begin{tabular}{|l|l|l|}
\hline & Yes & No \\
\hline Number & 151 & 75 \\
\hline Percentages & $68.81 \%$ & $31.19 \%$ \\
\hline
\end{tabular}

Table 6:Percentage of students regularly find information related to their studies

\begin{tabular}{|l|l|l|}
\hline & POSITIVE & NEGETIVE \\
\hline Number & 141 & 85 \\
\hline Percentages & $62.34 \%$ & $37.66 \%$ \\
\hline
\end{tabular}

Are you using Internet regularly to find information related to your course of study?

Table 6 Shows the response of NCE students on the question above that is use Internet regularly for accessing Internet $62.34 \%$ agreed while $22.66 \%$ did not agree which contradicted the findings of Table 2 in which only $50 \%$ ever operate computer.

\subsection{SUMMARY, CONCLUSION AND RECOMMENDATIONS}

This chapter summarizes, concludes and gives necessary recommendation about the research carried out for this work.

\subsection{Summary}

This research work is aimed to investigate and analyze the students' attitudes towards Internet USCOEGA in 20010/2011. The data were collected through questionnaire and analyzed by statistical techniques chi-square, percentages and barchart. Analysis revealed that students have limited awareness about the importance and the usage of Internet of Internet. And students are not relating their learning process with Internet.

\subsection{Conclusion}

This project work addressed an important topic related to the modern means of teaching and learning process, hence students' attitudes towards use of Internet. The result revealed that:

1. The students have limited awareness about the usage of Internet in the college.

2. There is no relationship between Internet usage and learning process among the students in USCEGA

3. Many students, from school of languages, NCE III of school of sciences and NCE II of school of vocational education have very limited knowledge on how to operate computer let alone accessing Internet. 
4. The amount been paid for Internet access in the college's Internetcafé discourages most students from using Internet;

5. Using Internet as well as computer operation has no relation with gender.

6. It is observed that most students are not given right information about themselves as required form the questionnaire.

\subsection{Recommendations}

Following the findings from the analysis made about the attitudes of NCE students of USCOEGA towards Internet in 2010/2010 session. The following recommendations are made:

1. More efforts should be intensified by the school of education to create awareness on the importance and the uses of Internet among the students as early as in NCE I;

2. School authority in conjunction with school of education should find a way to familiarize the NCE students on how to use Internet throughout their period of studies;

3. There is need for those responsible to drastically reduce the amount being paid for Internet use by the students to $50 \%$ but if possible free of charge or the fees should be in their school fees;

4. The students should develop the attitude of accessing Internet regularly, since it is believed that learning via Internet improves students' abilities to understand and evaluate the view of others;

5. Students should be well informed by the school of education to cooperate to researchers by giving them necessary and right information as required, as it may lead to the improvement of their learning condition;

6. The state and local governments in conjunction with their educational ministries or authorities should catch the students young in primary and secondary schools by giving them computer basic knowledge of information technology and this could give them appetitelnternet utilization in future study;

7. There is a great necessity to conduct more studies related to Internet with other variables or even improvement on this very research topic.

\section{ACKNOWLEDGMENTS}

My special thanks and appreciationsto the MalamSa'ad Ibrahimfrom Department of Education,Yobe State University as well as Mr.Aliyu I. Hong and MalamAbdulhamidDaudaboth from USCOEGA who have contributed immensely towards the success of this research.

\section{REFERENCES}

[1] Abu-Nasser, F. (2003). Current and Future Training Requirement for e-learning School Administration: Jordan Educative Perspective, Master's Thesis, Yarmouk University.

[2] Alex, O. O. (2009) Use of Electronic Resources By Postgraduate Students of Department of Library And Information Science of Delta State University Abrack Nigeria. Library Philosophy And Practice 2009 Available at $<$ www.webpages.uidaho.edu/ mbolin/oubah-alex.htm>

[3] Al-Najaar, A. (2001) The Reality Of Using Internet For Scientific Research For Staff At King Faisal University. Educational Researches Centre Journal, Qatar University, vol.10 no. 19 pp.135-160

[4] Al-Omary, M. (2002). The Reality of Staff and Student of Jordan University of Science and Technology Use of Internet. Arab University Journal, vol. 40 pp. 35-70.

[5] Al-Shayeed, A. (2001). The Reality of the Using Internet at Jordan University and their Attitudes toward It. Unpublished Master's Thesis, Yarmouk University pp 13-15.

[6] Anderson, J., Weert, V. T. (2002). Information and Communication Technology in Education. A Curriculum for Schools and Programme of Teacher Development. Division of Higher Education. UNESCO.

[7] Bome'rafi, B. (1996). The Reality of Using Internet by Shari'a University Staff. Journal of Education College, vol. 6 pp 112-118.

[8] Gittes, B. (1998). Informatics after Internet: Future Way. Knowledge World Kuwait,pp 320-321.

[9] Goodson, I. (2001)Social History of Educational Change. Journal of Educational Changevol. 2 no. 1 pp. 45-63

[10] Hong, K., Lai, W. \& Holton D. (2001). Web Base Learning Environment: Observation from a Web Base Course in a Malaysian Context.Australian Journal of Education Technology, vol. 33 no 2 pp. 417-431.

[11] Jebreen, M. and al-Karaki, J.(2008). Integrating Internet into Traditional Education: a Practical study of University Students' Usage and Attitude. The International Arab Journal of Information Technology, vol. 5, No. 3, pp 241- 250.

[12] Jones, (2002) Internet Goes to College: How Students are Living in The Future With Todays' Technology. Pew Internet \& American Life Project. Available at $<$ www.pewinternet.org $>$

[13] Joo, E. (1999). Cultural Issues of Internet in Classroom. British Journals of Educational Technology, vol. 30 No. 3 pp $245-250$

[14] Koohang, A. (2004). A Study of Users' perceptions Toward E-learning Courseware Usability, International Journals of E learning, vol. 3 no. 2, pp 25-52.

[15] Laite, B. (2000) Internet Use Survey: Analysis. [Accessed 20/10/2010] Available at:<www.ship.edu-bhl/survey/>

[16] Lall, Z. (2000). The Importance of Using Internet in the Educational process: Saudi University Faculty Perspectives. Journal of Al-Ta'awin, vol. 52, pp. 162-198.

[17] Lubani, J. (1998) How First Year University Students Use and Regard Internet Resources. [Accessed 20/10/2010] Available at: <www.lib.duke.edu/staff/orgnztn/ubans/docs/study3.httml> 
[18] Manal, O. (2000-2009,2010). Why Internet is So Addicted. [Accessed 29 September 2010]. Available at:<www.buzzle.com>

[19] Mulqueen, W. (2001) Technology In The Classroom: Lesson Learned Through Professional Departments. Educational Technology. Vol.122 no. 2 Pp. 248-268.

[20] Okon, E. (2010). Internet Access and Use: A study of UndergraduateStudents in three Nigerian Universities, Electronic Library,vol. 28 Iss: 4 pp 555-567.

[21] Rodney, S. (2002) The Integration Of Educational Technology Into Public Education: Promises And Challenges. Educational Technology, Vol. 8 no. 1 pp. 5

[22] Terasa, F. (2001) Internet Use In The Classroom: Potentials And Pitfalls For Student Learning And Teacher Student Relationships. Educational Technology. vol .41 no .3 pp. 57

[23] Warscbhaver, M., Turbee, L. and Robert, B. (1996). Computer Learning Network and Empowerment.Journal of System,24(1) pp 1-14.

[24] Jagboro, K. (2003) A study of Internet Usage in Nigerian Universities: A case Study of ObafemiAwolowo University, Ile-Ife, Nigeria.First Monday peer-reviewed journal on the internet. Vol. 8 no. 2-3. [Accessed 20/03/2010]. Available at:<http://ojphi.org/ojs/index.php/fm/article/view/1033>

[25] EDUCAUSE Center for Applied Research (2003) Supporting E-Learning in Higher Education: Impact and Challenge of E-Learning. $\quad$ Vol. 3 pp. 39-47. [Accessed 20/03/2010]. at:<www.educause.edu/ir/library/pdf/ers0303/rs/ers03036.pdf>

[26] Mortaza M. N. (2013) Research on Negative Effect on E-Learning.International Journal of Mobile Network Communications \& Telematics Vol. 3, No.2. [Accessed 20/04/2013]. Available at: <http://airccse.org/journal/ijmnct/papers/3213ijmnct02.pdf>

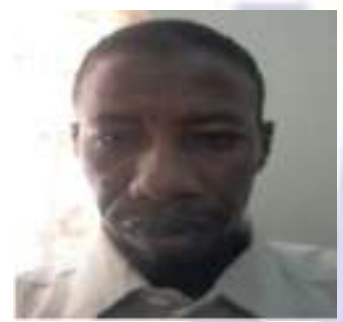

Appendix I

Mr. Abdulrahman Yusuf is at present an assistant Lecturer at the Department of Computer Science, Yobe State University, Nigeria. Yusuf pursued his M.Sc. and B.Sc. in Computer Science from University of Wolverhampton, UK and Bayero University Kano, Nigeria respectively. In addition, Mr. Yusuf has Diploma in Mathematic and Statistic and Post Graduate Diploma in education. He taught Mathematics and Computer courses to students of some institutions such as TTC Gwio Kura, USCOEGA and Yobe State University. His area of research interest include integrating Modern technology in teaching and learning, Database Technology, Mobile Computing and cloud security.

\section{Dear respondent, \\ QUESTIONANARE \\ Your objective responses are highly needed for this project: the information collected will be treated confidentially. Thank for your cooperation.}

A. General information about you. Tick only one box against each of the item below.
i) School: Vocational
Science [ ] Art and social science [ ] Languages [ ]
ii) Sex: Male [ ] Female [ ]
ii) Level: NCE I [ ] NCE II [ ] NCE III [ ]

B. Experiences: tick "Yes" or "No" base on your experiences in the questions below.

\begin{tabular}{|l|l|l|l|}
\hline S/N & \multicolumn{1}{|c|}{ QUESTIONS } & Yes & No \\
\hline i. & Have you ever been taught importance of Internet in your study here in the college? & & \\
\hline ii & Have you ever been thought how to use Internet here in the college? & & \\
\hline iii. & Have you ever operate computer for whatever purpose? & & \\
\hline iv & What stops students from using Internet is the token amount being paid for the service & & \\
\hline
\end{tabular}


C: How do you think about using Internet in teaching learning process (tick against SA, A, I, SD or D which stand for StronglyAgree, Agree, I don't know, Strongly Disagree and Disagree respectively about the expressions describe below below).

\begin{tabular}{|c|c|c|c|c|c|c|}
\hline S/NO. & EXPRESSIONS & SA & A & $\mathbf{I}$ & SD & D \\
\hline i. & I consider Internet as a source of learning information. & & & & & \\
\hline ii. & I belief that the use of Internet makes learning easier. & & & & & \\
\hline iii. & I don't think that one can get extensive knowledge through Internet. & & & & & \\
\hline iv. & $\begin{array}{l}\text { I believe that the use of Internet for academic purpose have impact on one's } \\
\text { achievement. }\end{array}$ & & & & & \\
\hline v. & I use e-learning site for the purpose of interaction with student. & & & & & \\
\hline vi. & I get enough support from the college to work with Internet. & & & & & \\
\hline vii. & I use Internet regularly to find information related to my course of study. & & & & & \\
\hline viii. & I don't believe that the use of Internet requires special skill & & & & & \\
\hline ix. & $\begin{array}{l}\text { I feel that learning via Internet improves one's ability to understand and evaluate the } \\
\text { views of others. }\end{array}$ & & & & & \\
\hline $\mathrm{x}$ & I think the research using Internet is just like the research using library. & & & & & \\
\hline
\end{tabular}

